\title{
High-Technology Trade: Does it Enhance National Competitiveness?
}

\author{
(Perdagangan Berteknologi Tinggi: Adakah ia dapat meningkatkan daya saing negara?)
}

\author{
Zera Zuryana Idris \\ International Islamic University Malaysia
}

\author{
Normaz Wana Ismail \\ Universiti Putra Malaysia \\ Saifuzzaman Ibrahim \\ Universiti Putra Malaysia \\ Hanny Zurina Hamzah \\ Universiti Putra Malaysia
}

\section{ABSTRACT}

This study aims to explore the impact of technological development through international trade activities on national competitiveness. As such, the objective of this paper is to empirically examine the impact of engaging in high-tech trade, both exports and imports, on national competitiveness. The research was carried out on a sample of 20 major high-tech exporting countries, over the period 2007 to 2016. An econometric analysis of panel data was employed. Considering the Global Competitiveness Index as the dependent variable, the results indicate that both high-tech exports and imports positively affect national competitiveness. Specifically, the exports of high-tech force technological development and improve national competitiveness. The imports of high-tech act as a mechanism for technology transfer and positively influence national competitiveness. The findings imply that it will be beneficial for a country to identify and develop potential high-tech industries in order to achieve a higher level of national competitiveness.

Keywords: International trade; national competitiveness; GCI; innovation; technology development JEL: F14, O33

ABSTRAK

Kajian ini bertujuan untuk melihat kesan perkembangan teknologi melalui aktiviti perdagangan antarabangsa terhadap tahap daya saing sesebuah negara. Oleh itu, objektif kertas ini adalah untuk mengkaji secara empirik kesan penglibatan dalam perdagangan berteknologi tinggi terhadap daya saing nasional. Kajian melibatkan sampel 20 negara pengeksport utama produk berteknologi tinggi, sepanjang tahun 2007 hingga 2016. Analisis ekonometrik data panel digunakan dalam kertas ini. Mengambil Indeks Daya Saing Global (GCI) sebagai pemboleh ubah bersandar, dapatan kajian menunjukkan bahawa eksport dan import berteknologi tinggi mempengaruhi daya saing negara secara positif. Secara khususnya, eksport berteknologi tinggi mendorong pengembangan teknologi dan peningkatan daya saing nasional. Import teknologi tinggi bertindak sebagai mekanisme pemindahan teknologi dan mempengaruhi daya saing nasional secara positif. Hasil kajian menunjukkan bahawa akan bermanfaat bagi sebuah negara untuk mengenal pasti dan mengembangkan industri teknologi tinggi yang berpotensi adalah bermanfaat untuk mencapai tahap daya saing nasional yang lebih tinggi.

Kata kunci: Perdagangan antarabangsa; daya saing nasional; GCI; inovasi; pengembangan teknologi

Received 26 February 2021; Revised 27 August 2021; Accepted 30 August 2021; Available online 3 September 2021

\section{INTRODUCTION}

Following the Industrial Revolution, the hightechnology (high-tech) trade is evolving. The emergence of new technologies makes it possible for countries to produce more technology-intensive goods. High-tech trade refers to the exports and imports of products of which the manufacturing involved high research and development (R\&D) intensity. The global high-tech exports show an increasing trend from 2000 to 2017 (Figure 1). The value of global high-tech exports amounted to 1.16 USD trillion in 2000. The value has increased by more than double to reach 2.69 USD trillion in 2017. In theory, high-tech products are more 
synonym with the developed countries due to the capital intensity of the products. However, recent data shows data the developing countries are increasingly becoming the exporter of high-tech products.

Figure 1 indicates that the growth rate of hightech exports from developing countries is higher than those of developed countries, given the steeper slope. Numerically, the high-tech exports of the developing countries grew by 436 percent from 188.9 billion USD in 2000 to 1013.08 billion USD in 2017. In contrast, the high-tech export from the developed countries increased by 72.6 percent from 969.10 billion USD in 2000 to 1672.70 billion USD in 2017. In a similar vein, the share of high-tech exports of the total manufactured exports from the developing countries is increasing from 2007 to 2018 and are higher than those of the developed countries from 2012 onwards (Figure 2). As of 2018, the high-tech exports from the developing countries make up around 22.20 percent of the total manufactured exports. The high-tech exports from the developed countries, on the other hand, make up only around 20.22 percent of the total manufactured exports.

Unlike normal trade, the expansion of high-tech trade is highly associated with rapid technological change and innovation. Previous studies documented a positive relationship between high-tech exports and

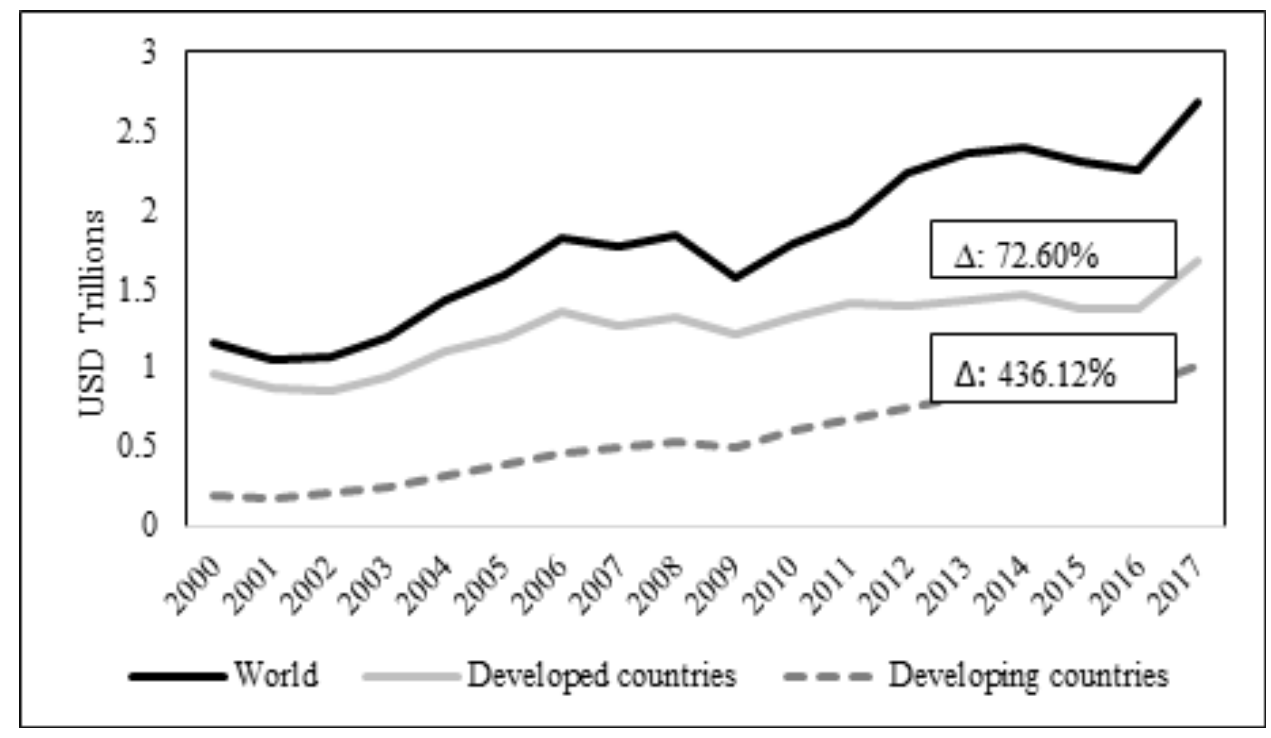

FIGURE 1 High-tech Exports, 2000-2017

Source: World Development Indicator

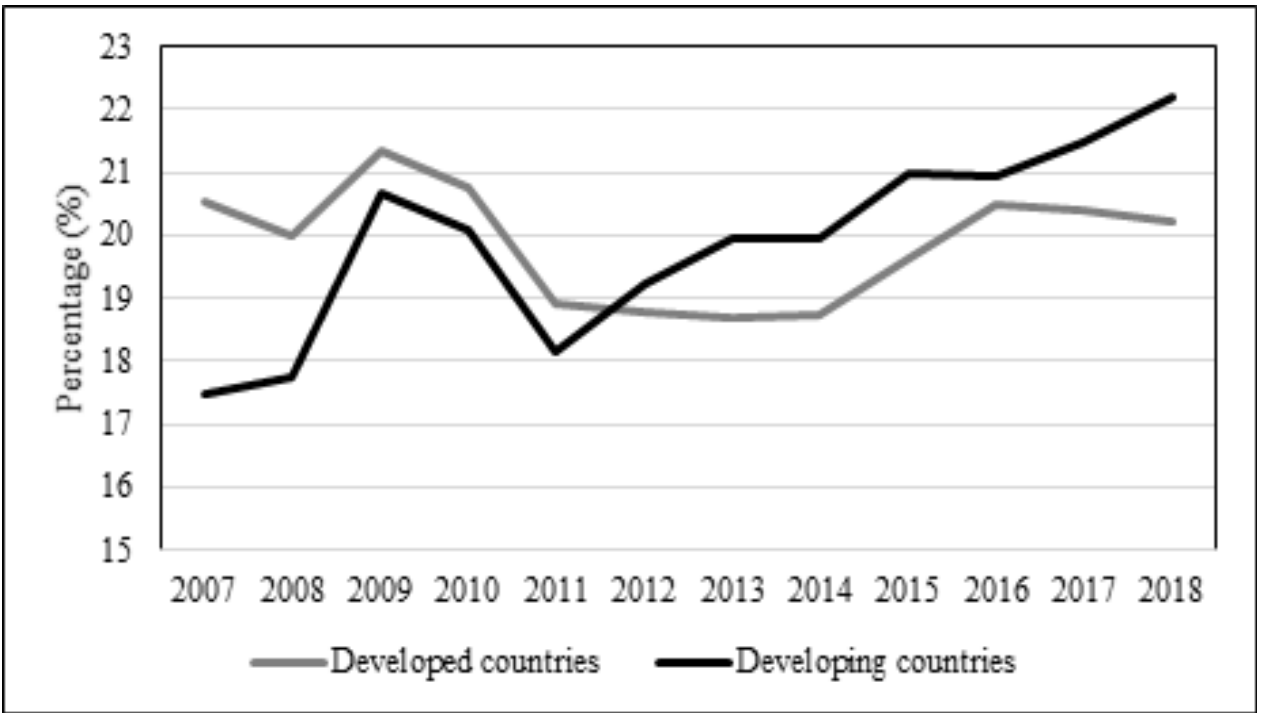

FIGURE 2. High-technology exports (\% of manufactured exports), 2007-2018

Source: World Development Indicator 
innovation (Ismail 2013; Sandu \& Ciocanel 2014). As countries increase their high-tech exports, it is expected that they will engage in more innovation activities. Several authors claimed that innovation enhances national competitiveness (Chen 2013; Gani 2008). In the Porter's Diamond Model (1990), technological development was highlighted as one of the determinants of national competitiveness. Apart from innovation, previous literatures also highlighted several ways in which international trade can enhance national competitiveness.

First, international trade forces countries to improve their institutional quality through the 'race to the top' (Levchenko 2011) hypothesis. After opening for international trade, countries will eventually improve their macroeconomic conditions including contract enforcement, property rights, and investor protection to remain competitive in the world market. Second, international trade forces countries to involve in a continuous innovative activity. To compete in the international market and achieve sustainable long-run growth, countries must continue to innovate (Romer 1990). Through innovation, pillars of competitiveness such as infrastructure, quality, and skilled workforces, conducive trading environment, and business sophistication should have improved. Apart from producing and exporting, national competitiveness can be enhanced through imports. Imports allow countries to minimise production costs and acquire highquality inputs from other countries. As a result, they can specialise in their field of expertise and enhance productivity and competitiveness. Finally, imports serve as a channel for technology transfer. The technology embodied in the imported goods may increase the productivity of the importing country, and there may be import-related learning effects (Acharya \& Keller 2007).

Given the several possible ways in which innovation and international trade can affect national competitiveness, engaging in the high-tech trade which is said to be highly correlated with innovation is expected to have a positive spill over on the national competitiveness level of a country. However, the competitiveness level of the high-tech exporting countries particularly those from the developing countries group is not satisfactory (Figure 3). The Global Competitiveness Index (GCI) of the high-tech exporting countries from the developing countries group are below those of developed countries. An extreme case is China; despite being the largest exporter of high-tech goods, its competitiveness score remains below the 5.00 index point.

Reviewing in terms of the most competitive countries in the world, the top 20 countries are developed countries (Table 1). Although the developing countries are increasingly exporting high-tech goods as illustrated in Figure 1 and 2, the only developing country that is listed closely to those developed countries is Malaysia that is the $23^{\text {rd }}$ rank. Meanwhile, the largest global high-tech exporter, China, ranked far below Malaysia that is at $27^{\text {th }}$ rank. Not only that, although the position of the high-tech exporters coming from the developed countries is better than those of the developing countries, they are also overtaken by those who are not the major high-tech exporters such as Sweden. Thus, it poses a question of whether engaging in high-tech trade could affect national competitiveness positively.

TABLE 1. Global Competitiveness Index Ranking, 2017

\begin{tabular}{cccc}
\hline Rank & Country & Income Group & Score \\
\hline 1 & Switzerland & High-income & 5.86 \\
2 & United States & High-income & 5.85 \\
3 & Singapore & High-income & 5.71 \\
4 & Netherlands & High-income & 5.66 \\
5 & Germany & High-income & 5.65 \\
6 & Hong Kong & High-income & 5.53 \\
7 & Sweden & High-income & 5.52 \\
8 & United Kingdom & High-income & 5.51 \\
9 & Japan & High-income & 5.49 \\
10 & Finland & High-income & 5.49 \\
11 & Norway & High-income & 5.4 \\
12 & Denmark & High-income & 5.39 \\
13 & New Zealand & High-income & 5.37 \\
14 & Canada & High-income & 5.35 \\
15 & Taiwan & High-income & 5.33 \\
16 & Israel & High-income & 5.31 \\
17 & United Arab Emirates & High-income & 5.3 \\
18 & Austria & High-income & 5.25 \\
19 & Luxembourg & High-income & 5.23 \\
20 & Belgium & High-income & 5.23 \\
23 & Malaysia & Upper-middle & 5.17 \\
& & income & \\
27 & China & Upper-middle & 5.00 \\
& & income & \\
\hline
\end{tabular}

Source: Global Competitiveness Report 2017-2018, World Economic Forum (WEF)

Theoretically, innovation and international trade should have improved national competitiveness. While exporting high-tech products forces countries to improve their economic environment, importing high-tech products is possible to increase national competitiveness through an increase in productivity, reduction in manufacturing costs, enhanced specialisation, and import-related learning effects. While discussing the expansion of high-tech trade, previous literature highlighted the determinant of high-tech trade (Ismail 2013; Kabaklarli et al. 2017; Mehrara et al. 2017; Sandu 


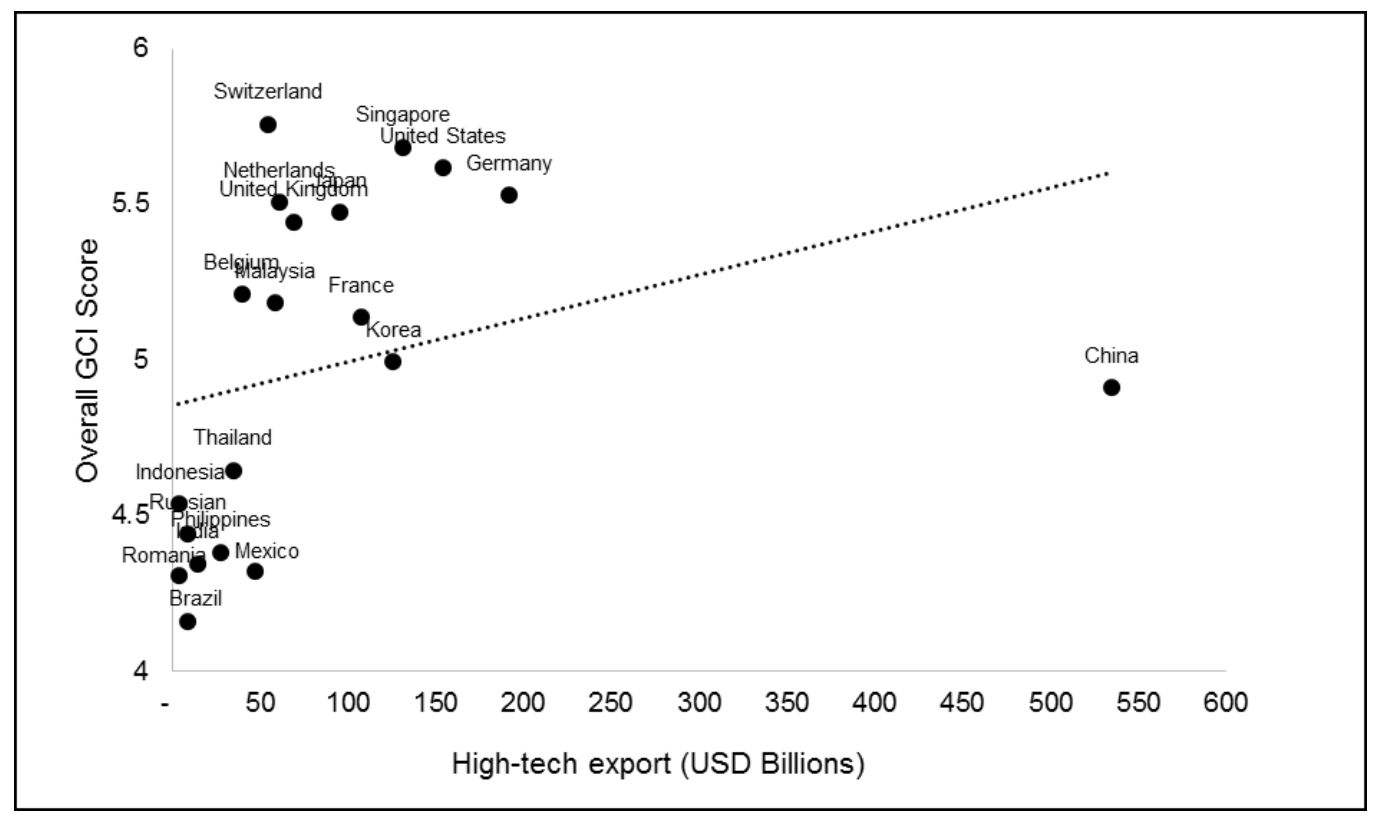

FIGURE 3. GCI Score and high-tech exports, average 2014-2016

Source: Global Competitiveness Report and World Development Indicator

\& Ciocanel 2014). Little emphasis has been given to study the impact of high-tech trade. Thus far, previous studies concerning the impact of high-tech trade focus on economic growth (Demir 2018; Erkananda \& Parlinggoman, 2017; Wabiga \& Nakijoba 2018) and innovative capability (Wu et al. 2017) only. Despite this worthy effort, they do not take into account the possible impact of high-tech trade on overall economic conditions that can arise through exports and imports of high-tech products. Taking lead from the literature, this paper aims to examine the impact of high-tech trade on national competitiveness.

The remainder of this paper is structured as follows. The following section, Section 2, will discuss related literature about the issue. This is followed by an empirical strategy that consists of model specification and method of estimation used to address the research objective in Section 3. Section 4 presents results and discussion. Section 5 provides a conclusion, policy implications, and suggestions for future research.

\section{LITERATURE REVIEW}

\section{DEFINITION OF NATIONAL COMPETITIVENESS}

Prior to examining the impact of high-tech trade on national competitiveness, there is a need to establish a clear definition of national competitiveness. Despite being promoted by various media and widely used in public-policy speech, there is no clear consensus on the definition of national competitiveness. Defining competitiveness is a controversial issue (Aiginger
1998), especially at the national level. Charrass (2017) highlighted one of the reasons is due to the scope of the concept. Competitiveness is a microeconomic concept that deteriorates when it is applied at the national level simply because countries do not compete like firms. Unlike firms, countries do not have a bottom line to define their performance like profits. Krugman (1994) described competitiveness as a dangerous obsession and is a meaningless word when applied to national economies.

The term competitiveness is normally presented as a comparative measure, and that leads many people to look at competitiveness as a zero-sum game. National competitiveness should not be portrayed as competition in the sporting sense where one party wins at the expense of others. It is possible for all countries to improve all at once. A country may improve its competitiveness conditions from previous years but may still be relatively uncompetitive as compared to other countries. Furthermore, countries do not compete as firms do but compete in creating attractive conditions for investors (Taner et al. 2000). Different scholars have different concepts and arguments on the definition of competitiveness (Appendix A). Over time, the consensus of defining national competitiveness seems to be converging to the ability to create welfare (Aiginger 2006).

According to Schwab (2018), competitiveness is defined as "a set of institutions, policies, and factors that determine the level of productivity of a country". In this context, national competitiveness refers to the national conditions that reflect the potential of a nation to achieve higher productivity, increase prosperity, 
achieve a high standard of living, and generate a high rate of employment (Porter 1990; Tomas 2011).

Figure 4 illustrates the concept of national competitiveness. Competitiveness should be taken differently than productivity. While productivity represents a characteristic of an entity, competitiveness refers to its position compared to other entities (Onsel et al., 2008). The concept of competitiveness explained above involves all the vital microeconomic and macroeconomic foundations required for a nation to compete in the international market to produce goods or services that meet global demand and enhance domestic well-being. Competitiveness requires multidimensional measures (Buckley et al. 1988; Siudek \& Zawojska 2014). In this study, national competitiveness is defined as the ability of a nation to achieve higher productivity, prosperity, and economic well-being.

\section{HIGH-TECH TRADE AND COMPETITIVENESS}

International trade and competitiveness are closely related. In a very integrated world, countries earn benefits from international trade with different competitive strategies. Levchenko (2011) demonstrated that there is a 'race to the top' effect resulting from international trade activities. In the event where two countries share the same technological capability, international trade forces trade the countries to improve the domestic economic environment such as the institutional quality to compete in the market. Drawing upon this scenario, it is expected that the economic environment will be improved as a result of participating in international trade. Baldwin et al. (2015) identified two channels in which international trade can benefit countries. First, it creates larger market opportunities through larger market sizes to domestic firms. Second, it drives productivity and innovation through exposure to international competition, expertise, and technology. Through these channels, trade contributes to the enhancement of the basic economic environment such as infrastructure, economic growth, and institution; enhance market efficiency and also increase the innovative capacity of a nation. Besides exports, national competitiveness is likely to be influenced through imports. International trade enables a country to employ foreign intermediate or capital goods, increase communication between countries to facilitate resource allocation, help the developing countries to imitate technology, and raise the country's productivity while creating new technologies (Coe et al. 1997).

Both innovation and international trade have the potential to increase national competitiveness. A strand of literature highlighted the importance of innovation (Acharya \& Keller 2007; Delgado et al., 2012) to improve economic conditions. These studies conclude that innovation positively contributes to the productivity of an economy. High-tech trade is highly embedded in innovative activities. Hence, engaging in high-tech trade is expected to increase productivity. An increase in productivity can be translated into an increase in income level and the well-being of a country. Simultaneously, we expect an increase in national competitiveness. Tomas (2011) definition of competitiveness includes the quality of human life. Therefore, the Human Development Index (HDI) was used as a measure of competitiveness. This study suggests that innovation activities can contribute to raising the quality of life. Hence, we could hypothesise that engaging in high-tech trade could affect national competitiveness positively. On a similar note, previous literatures highlighted the importance of technological development on international (Fagerberg 1988; Fagerberg et al. 2007) and national (Wang et al. 2007) competitiveness. Taking international competitiveness as the success of a country to secure larger export shares in the world market, Fagerberg (1988) and Fagerberg et al. (2007) presented that technological development is positively related to international competitiveness. High technological development allows countries to produce more sophisticated products and penetrate larger

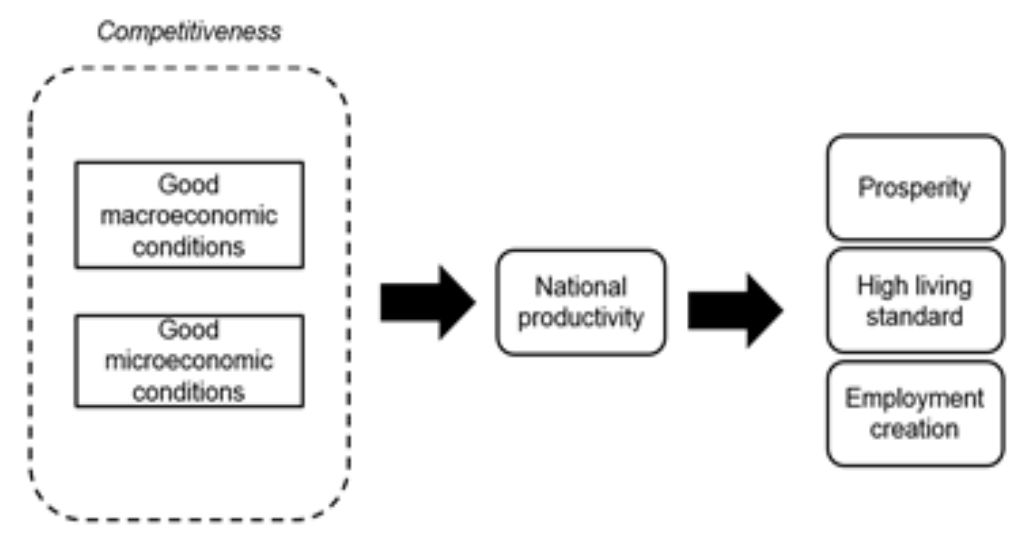

FIGURE 4. Illustration of the definition and concept of competitiveness Source: Author's illustration 
exports market. As such, technological development is expected to elevate countries' position to compete in the international market. If high-tech trade increases technological development in a country, it is expected that its national competitiveness will also increase.

Regarding the impact of international trade on national competitiveness, Atkin, Khandelwal, and Osman (2017) showed that exports increase product quality and improve technical efficiency. In a randomised experiment, they showed that when exporters are given larger market opportunities through exports, more quality control will be adopted by the exporting firms. Indirectly, this contributed to enhanced product quality exported by a country and increase the position of the country to compete in the international market. This supports Liu and Buck (2007), which report that learning-by-exporting and importing promotes innovation. Innovation matters for national competitiveness; however, the developing countries should not use the pattern of specialisation of the developed countries as the yardstick (Fagerberg 1996). Falvey et al. (2002) emphasised that international trade facilitates knowledge spillovers and transfers between countries. The higher the level of trade, the higher the knowledge transfer is expected. Knowledge transfer is among the important drivers of industry clusters that could lead to global competitiveness. Given the hightechnological content embedded in high-tech products, we hypothesised that the exports and imports of hightech would involve more knowledge transfer. In turn, countries will improve their national competitiveness by engaging in high-tech trade.

There are several studies that attempted to link hightech trade and an element of national competitiveness i.e., economic growth. Demir (2018), Falk (2009), and Seung-Hoo (2008) showed that high-tech exports are positively influenced economic growth. While countries export more high-tech products, they will experience more economic growth. These studies are in line with Gani (2008), which showed that high-tech exports exhibit a positive and significant relationship with economic growth in the case of technological leader countries. Putting this in our context, high-economic growth could later be translated to an increase in national competitiveness. High economic growth enables countries to achieve higher productivity, prosperity, and economic well-being. On the contrary, Erkananda and Parlinggoman (2017) found that high-tech exports have no significant impact on economic growth. This was due to the small changes in the ratio of high-tech exports to GDP. Using a time-series study, Wabiga and Nakijoba (2018) demonstrated that high-tech exports do not have a significant effect on economic growth in the short run. However, the effect is improving in the long run.

Wu et al. (2017) studied the impact of high-tech exports on innovative capability. They document a positive relationship between high-tech exports and the innovative capability of a country. High-tech exports improve the ability of the emerging countries to produce new technologies. However, Bao et al. (2012) found that high-tech exports do not lead to technology spillover to domestic sectors or other export sectors in China. This finding can be attributed to the fact that China's hightechnology exports depend significantly on processing trade and foreign direct investment. This dependency has limited the opportunity for technology learning. In this setting, high-tech exports may not contribute to increasing national competitiveness. This study is in line with Srholec (2007) and Xing (2014), which highlighted the characteristics of the high-tech products traded. Srholec (2007) highlighted that the bulk of high-tech exports from developing countries are highly associated with their participation in the fragmented global production network. Xing (2014) argued that the high-tech exports from developing countries like China are based on assembled high-tech products and therefore are indifferent from other labour-intensive products in terms of technological intensity. If countries are concentrating at the lower end of such production network such as assembling the high-tech products, then exporting high-tech products with minimal domestic value-added means less to their ability to grow.

Besides focusing on the role of high-tech exports, several studies examined the impact of high-tech imports on economic growth (Belitz \& Mölders 2013; Busse \& Groizard 2007). In both studies, a positive linkage between technology imports and income levels was recorded. Busse and Groizard (2007) argued that high-tech imports are a more appropriate measure of technology diffusion rather than overall trade. This is due to the technological content embedded in the products. Importing technology is a way of accumulating capital goods that could contribute positively to the total factor productivity of a country. Belitz and Mölders (2013) added that developing countries enjoy additional spillover from importing high-tech goods as compared to industrial countries.

Despite the worthy effort made by the previous studies in estimating the impact of high-tech trade, the scope of these studies remains limited to only one aspect of competitiveness, i.e., economic performance. Buckley et al. (1988) suggested the concept of competitiveness should encompass three important elements, which are performance, potential, and process. Performance measures competitiveness in terms of output performance, such as export market share. Potential measures competitiveness in terms of inputs such as price and technology indicators. Process measures competitiveness in terms of the management part, such as government policies. Therefore, using a single measure such as economic growth cannot capture the impact of high-tech trade on the overall economic conditions. Taking the lead from the literature, this study attempt to examine the impact of high-tech trade on a more comprehensive aspect of competitiveness. 


\section{DATA AND METHODOLOGY}

\section{MODEL SPECIFICATION}

To examine the impact of high-tech trade on national competitiveness, this study adopted the competitiveness model as presented in Fagerberg et al. (2007). This model assumes the competitiveness of a country depends on the potential for technology diffusion, the growth in technological competitiveness, the growth in capacity competitiveness, the growth in price competitiveness, and demand competitiveness. In their paper, the model specification can be written as follows:

$$
y_{i}=\alpha_{0}+\alpha_{1} P T D_{i}+\alpha_{2} T_{i}+\alpha_{3} C_{i}+\alpha_{4} P_{i}+\alpha_{5} w_{i}+v_{i}
$$

In Equation 1, $y$ denotes the national competitiveness of country $i$ measured using the rate of economic growth. The PTDi represents the potential for technological diffusion. According to Fagerberg et al. (2007), the potential for technological diffusion is measured as the distance in technological knowledge between country $i$ and the most advanced countries in the sample. The potential for technological diffusion is calculated as follows:

$$
P T D_{i}=\frac{T K_{i}}{T K^{*}}
$$

$T K_{i}$ is the technological knowledge of country $i$ and $T K^{*}$ is the technological knowledge appropriated in the most advanced countries in the sample. The $P T D_{i}$ measures the distance in technological knowledge between country $i$ and the technological frontier. The interpretation of this variable is based on Solow's (1956) theory of growth in which it reflects the potential for a catch-up. This theory predicts that poorer countries will grow at a faster rate than the developed countries based on the law of diminishing return. In this case, the expected sign of $\alpha_{1}$ is negative. However, this theory was contested by Abramovitz (1986) where he argued that the ability to catch up effect will not occur without social capabilities. Social capabilities include the ability to adopt and absorb technology, promote investment and participation in the global market. Furthermore, the pace at which a country adopts and absorbs technologies depends on many factors, including having a technologically literate workforce, the ability to attract investment (World Bank 2008), and other supporting conditions (Porter 1990) to promote the diffusion of technologies. Obtaining these abilities are made possible with a higher level of income. For example, countries with higher income are able to develop better infrastructure to attract investment. This will later facilitate the process of technological diffusion and contribute positively to enhance national competitiveness. In this case, $\alpha_{1}$ may exhibit a positive sign. Since it is challenging to find the level of technological knowledge appropriated in a country relative to the technological frontier, the log of initial GDP per capita was used instead following Fagerberg et al. (2007).

$T_{i}$ in Equation 1 denotes technological competitiveness of country $i$. It refers to the ability of a country to compete in markets for new goods and services. Higher technological competitiveness is expected to contribute positively to national competitiveness. Hence, the a priori expectation for $\alpha_{2}$ is positive. $C_{i}$ denotes capacity competitiveness. It measures the capability of a country to exploit technology and reflects the level of competency of a country. Higher competency results in higher competitiveness. Therefore, $\alpha_{3}$ is expected to be positive. The $P_{i}$ denotes price competitiveness. It refers to the ability of a country to offer low-cost production. The lower cost they can offer, the more competitive it tends to be. Therefore, we predict $\alpha_{4}$ to exhibit a negative sign. $W i$ reflects demand competitiveness. It refers to the ability to meet world demand which is represented as the amount of export. Export has the potential to increase national competitiveness as larger markets drive labour efficiency, product development and improve other economic environments. $\alpha_{5}$ is expected to be positive due to the positive relationship between world demand and the economic growth rate.

Augmenting the original equation as in Equation 1, we include high-tech variables to examine the impact of high-tech trade on national competitiveness. To examine the impact of high-tech trade on national competitiveness, the following models are estimated:

$$
\begin{aligned}
& N C_{i t}=\alpha_{0}+\alpha_{1} P T D_{i}+\alpha_{2} T_{i t}+\alpha_{3} C_{i t}+\alpha_{4} P_{i t}+\alpha_{5} T T_{i t}+\varepsilon_{i t} \\
& N C_{i t}=\alpha_{0}+\alpha_{1} P T D_{i}+\alpha_{2} T_{i t}+\alpha_{3} C_{i t}+\alpha_{4} P_{i t}+\alpha_{5} X T_{i t}+\varepsilon_{i t} \\
& N C_{i t}=\alpha_{0}+\alpha_{1} P T D_{i}+\alpha_{2} T_{i t}+\alpha_{3} C_{i t}+\alpha_{4} P_{i t}+\alpha_{5} M T_{i t}+\varepsilon_{i t}
\end{aligned}
$$

In Equation 3, 4, and 5, the $N C_{i t}$ is the level of national competitiveness of country $i$ at time $t$. The $\alpha_{0}$. is a constant term that is common for all countries in all years. Instead of using a single measure such as economic growth to measure competitiveness, this study uses Global Competitiveness Index as produced by the World Economic Forum (WEF). This is the most widely accepted measure of national competitiveness. It assesses the ability of countries to achieve growth and provide high living standards to their citizens. Following GCI, the competitiveness of a country comprises elements such as institutions, infrastructure, macroeconomic environment, health and primary education, higher education and training, goods market efficiency, financial market development, technological readiness, market size, business sophistication, and $\mathrm{R} \& \mathrm{D}$ innovation. 
The $P T D_{i}$ is the potential for technological diffusion of country $i$. Following Fagerberg et al. (2007), the log of GDP per capita was used to represent the potential for technological diffusion. $T_{i t}$ measures the technological competitiveness of country $i$ at time $t$. $C_{i t}$ denotes capacity competitiveness measures the capability of a country to exploit technology. It measures the level of competency of a country $i$ at time $t$. The $P_{i t}$ denotes price competitiveness.

In Equations 3, 4, and 5, the high-tech variables were included in turn. Equations 3, 4, and 5 examine the impact of high-tech total trade (TT), high-tech exports (XT), and high-tech imports (MT) on national competitiveness, respectively. $T T_{i t}$ is the value of the total high-tech trade (exports and imports) of country $i$ at time $t . X T_{i t}$ denotes the value of total high-tech exports from country $i$ to the world at time $t$. While $M T_{i t}$. is the value of total high-tech imports of the country from the world $i$ at time $t$.

According to Levchenko (2011), international trade forces countries to improve institutional quality after opening through 'race to the top' (Levchenko 2011). Exporting high-tech products forces countries to improve their economic environment, such as infrastructure, intellectual property rights, human capital, etc. These are expected to contribute to the competitiveness of a country. Hence, $\alpha_{5}$ in Equation 4 is expected to exhibit a positive sign. Apart from high-tech export, import also has the potential to contribute positively to national competitiveness. Eaton and Kortum (1999) showed that research efforts depend on ideas earned at home and abroad. Imports help the developing countries to imitate technology and raise the country's productivity while creating new technologies (Coe et al, 1997). Similar to exports, we predict that the imports igh-tech will contribute to national competitiveness positively. The $a$ priori expectation for $\alpha_{5}$ in Equation 5 is positiveGiven the positive effect that both high-tech exports and imports may have on national competitiveness, the $a$ priori expection for $\alpha_{5}$ in Equation 3 should also be positive.

\section{DATA DESCRIPTION}

This study involves a sample of 20 high-tech exporting countries. A list of high-tech exporting countries is identified from the World Development Indicator database to select these countries. This list was then divided into two groups, i.e., developed a developing, based on their income classification. Subsequently, the top 10 countries are chosen from the developed countries group, and the top 10 countries are chosen from the developing countries group. The selected sample countries are Germany, the United States of America (USA), Singapore, Korea, France, Japan, United Kingdom, Switzerland, Netherlands, Belgium,
China, Malaysia, Mexico, Thailand, Philippines, India, Brazil, Russian Federation, Romania, and Indonesia. The period for this study is from 2007 to 2016, given the availability of high-tech trade data. This study utilised trade and economic data from various sources to examine the impact of high-tech trade on national competitive. The dependent variable in this model is the GCI score. The GCI score fits our definition of national competitiveness. By using such a composite index, our measurement of competitiveness is comprehensive and does not based on a single measure only. As suggested by Buckley et al. (1988), a useful measure of competitiveness should include competitive performance, competitive potential, and competitive process. This study utilised the GCI score as a measure of a country's performance relative to other countries instead of growth rate. The data can be obtained from a series of Global Competitiveness Report produced by WEF yearly.

The core explanatory variable in this analysis is the high-tech trade. The data for high-tech trade in this study will be in terms of total trade, exports, and imports. From the UN COMTRADE database, the values for high-tech exports and imports were extracted. This data is derived by product line using SITC Rev. 4 codes and then summed up to get the total high-tech exports, imports, and trade for each country in each year.

As suggested in Fagerberg et al. (2007), the potential for technological diffusion is measured by the difference between the level of technology appropriated incountry $i$ and the most advanced country in the sample. However, it is challenging to find an approximation for the total level of technology appropriated in a country relative to the frontier (the most advanced country in the sample). Following Fagerberg et al. (2007), we use the $\log$ of the initial level of GDP per capita to calculate the potential for diffusion.

The technological competitiveness is proxied by the technological readiness index obtained from the World Bank. The technology readiness index measures the propensity for countries to exploit the opportunities offered by information and communications technology (Breene 2016). Capacity competitiveness is measured by the capacity for innovation index obtained from the World Bank. This measures the ability of a country to innovate. The price competitiveness is proxied by the labour cost obtained from the World Bank. It represents the ability of a country to produce at cheaper costs.

\section{METHOD OF ESTIMATION}

This study involves a panel dataset. Hence, to examine the impact of high-tech trade on national competitiveness, this paper follows the standard panel data estimation methods. Generally, there are three common methods of estimation for panel data: Panel Ordinary Least Squares (POLS), Random Effect Model 
(REM), and Fixed Effect Model (FEM). The POLS assumes all countries as homogenous while the latter two allow for countries' heterogeneity. The REM and FEM decompose the random error term into individual specific-effect and the remainder error term. The REM assumes the individual specific effect is drawn independently from some probability distribution, while the FEM assumes the individual specific effect as a fixed constant. Breusch-Pagan LM test and Hausman test will be performed to choose the appropriate model.

Besides, we also estimate the dynamic model of competitiveness. The common issue in a dynamic model is endogeneity that is the non-zero correlation between the lagged-dependent variable and the individualspecific effect. To deal with the endogeneity, Arellano and Bond (1991) proposed a differenced Generalised Method of Moments (GMM) while Blundell and Bond (1998) introduced the system GMM. Even though GMM is widely used for endogeneity issues, the estimators can have poor finite sample properties and are unsuitable for small samples according to Meschi and Vivarelli (2009). Given the small sample in this study, we use the Biascorrected Least Square Dummy Variable (LSDVC) estimation techniques as proposed by Kiviet (1995), Judson and Owen (1999), Bun and Kiviet (2003), and Bruno (2005a, 2005b) proposed LSDVC.

\section{RESULTS AND DISCUSSION}

\section{EMPIRICAL RESULT}

Table 2 presents the empirical result for the impact of high-tech trade on national competitiveness. Column (1) to (3) presents the result using the POLS estimation method. Taking all countries as homogenous, the result suggests that high-tech trade is significantly positively affecting national competitiveness (Colum 1). The coefficient is positive and statistically significant at a 0.01 percent level of significance. Empirically, a one percent increase in high-tech trade will increase the GCI index by 0.12 points. Individually, both high-tech exports and high-tech imports exhibit positive signs indicating the positive effect of high-tech exports and imports on national competitiveness. In terms of magnitude, there is not much difference between the impact of high-tech exports and imports. The expected signs for all other variables are in accordance with the a priori expectation. However, we find no significant evidence with regards to the impact of potential for technological diffusion and price competitiveness on national competitiveness.

The POLS is the most commonly used method in econometric analysis, however, the estimates are not necessarily consistent. Muller and Wei (1997) suggest an iterative regression procedure is proposed to produce consistent estimates. We re-estimate the equation using the iteratively re-weighted least squares as implemented in Fagerberg et al. (2007). This method is robust to the inclusion of outliers. The estimation results are presented in Columns (4) to (6). The results suggest that the presence of outliers has little impact on the estimates. Column (4) suggests that engaging in high-tech trade will increase the national competitiveness of a country. One percent increase in high-tech trade will induce the GCI score to increase by 0.1 points. The coefficient for high-tech exports is also positive and significant at a 99 percent confidence interval (Column 5). A one percent increase in high-tech exports will boost the GCI score by 0.1 points. We document the same result and magnitude in the case of high-tech imports (Column 6).

The Breusch-Pagan LM test was conducted to determine whether there are country-specific effects in the data. The p-values are below 0.05 leading to the rejection of the null hypothesis. In other words, there are country-specific effects in the data. Taking the country heterogeneity into consideration, we proceed by estimating the REM and FEM. Columns (7) to (9) present the estimation result from the REM. The results hold the same conclusion as in the estimation of POLS and iterative OLS. High-tech trade is positively and significantly affecting national competitiveness. Columns (11) to (10) present results for the impact of high-tech trade on national competitiveness using the FEM. From the result, we observe that the hightech trade in aggregate positively affects national competitiveness (Column 11). The coefficient for hightech exports is positive and significant suggesting the positive relationship between high-tech exports and national competitiveness. On the other hand, high-tech imports are found to be positive but insignificant. The Hausman test was conducted to select the appropriate model. The results suggest that FEM is preferred.

Our result confirms that engaging in high-tech trade could enhance national competitiveness. As prescribed by Porter (1990) national competitiveness depends on the capacity to innovate and upgrade. Unlike normal trade, high-tech trade is highly associated with technological advancement and innovative activities. High-tech trade encourages innovation activities in a country which later contributes to increasing national ability to achieve higher productivity, prosperity, and economic well-being. The impact of high-tech trade on national competitiveness supports the 'race to the top' theory as presented in Levchenko (2011). Hightech trade activities force the countries to improve the domestic economic environment such as the institutional quality to compete in the market.

With regards to the impact of high-tech exports on national competitiveness, our findings are in line with Demir (2018), Falk (2009), Gani (2008), Seung-Hoo (2008), and Wu et al. (2017). High-tech exports increase economic growth and innovative capability. It exposes the high-tech firms to larger market opportunities. To be able to compete in international markets, firms 


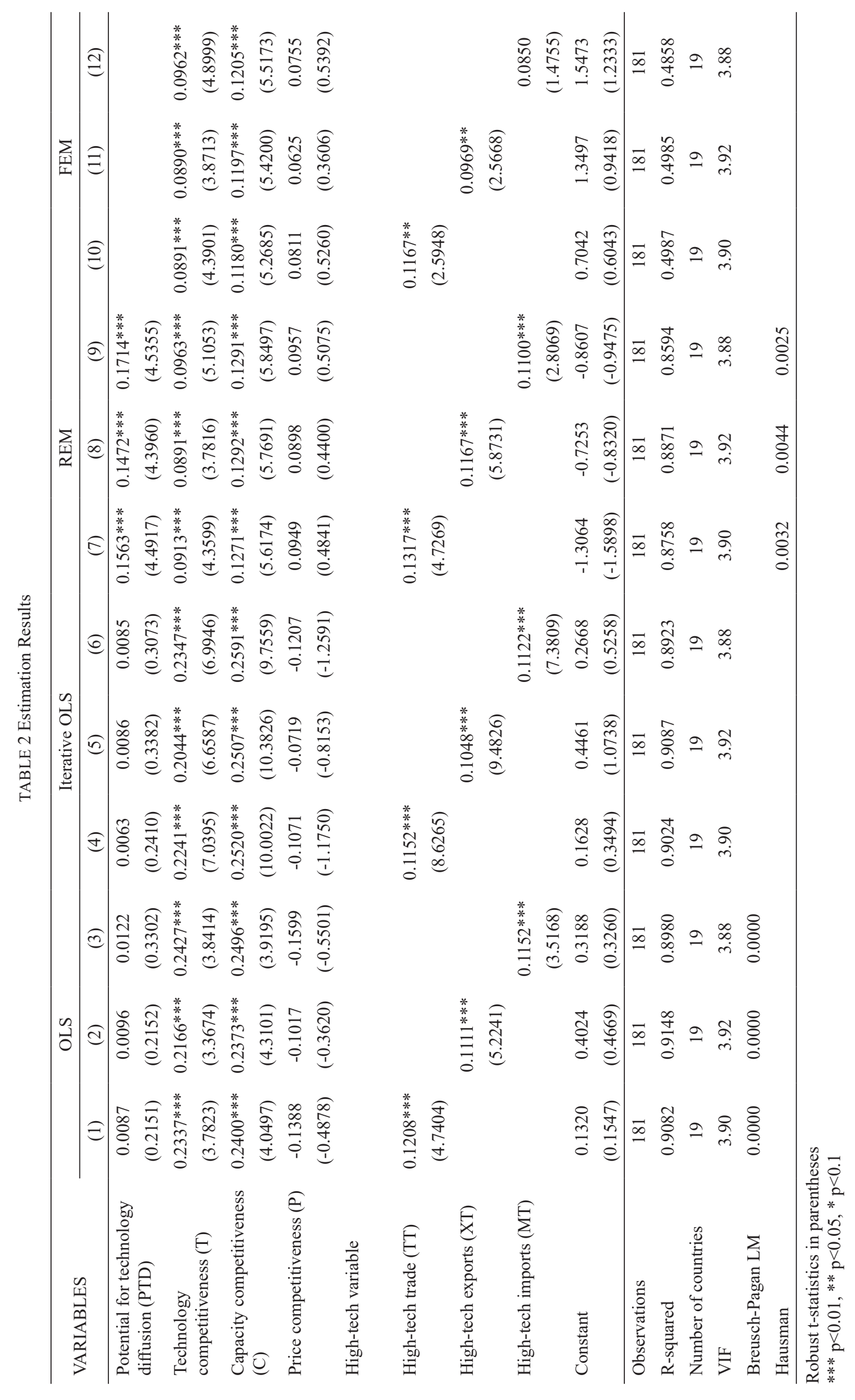


need extensive innovative efforts. High-tech exports drive productivity (Erkananda \& Parlinggoman 2017) and innovation through exposure to international competition, expertise, and technology (Baldwin et al., 2015). This later will result in an increase in national competitiveness.

Literaturealso suggests thatnational competitiveness is likely to be influenced by imports (Coe et al. 1997). Our result shows that high-tech imports are positively related to national competitiveness. The coefficient of high-tech imports is positive and in all models except under FEM. As documented in Busse and Groizard (2007) and Belitz and Mölders (2013), the technological content embedded in the products provides spillover to the economic growth and income level in a country. In the same notion, high-tech imports enhance national competitiveness. International trade enables a country to employ foreign intermediate or capital goods, increase communication between countries to facilitate resource allocation, help the developing countries to imitate technology, and raise the country's productivity while creating new technologies.

\section{ROBUSTNESS: EXPLORING THE DYNAMIC OF COMPETITIVENESS}

Porter's model of competitiveness was being criticised because it does not elaborate on the dynamic process of factors determining competitiveness (Dayasindhu 2002). Buckley et al. (1988) argued that competitiveness encompasses three important elements, i.e., performance, potential, and process. As such, competitiveness should be taken as an ongoing and dynamic process rather than static. Similarly, Aiginger (1998), Dayasindhu (2002), Delgado et al. (2012), and Onsel et al. (2008) argued that competitiveness should be perceived as dynamic in nature. The Bias-corrected Least Square Dummy Variable (LSDVC) estimator was initialised using Arellano and Bond (1991). Taking the lead from this argument, we estimate a dynamic model of competitiveness. Following Bruno (2005b), the standard errors are bootstraps with 100 iterations to assess the statistical significance of the LSDVC coefficients.

The result is presented in Table 3. The result confirms the path-dependency of competitiveness. The lagged of the dependent variable is positive and significant at a 1 percent level of significance. The coefficient of hightech trade is positive and significant supporting the positive relationship of high-tech trade and national competitiveness. In addition, both high-tech exports and imports also exhibit a positive impact on national competitiveness. All other variables are following the expected signs. However, price competitiveness is insignificant. This is in line with Fagerberg et al. (2007) who found that price competitiveness is trivial as compared to other aspects of competitiveness.
TABLE 3 Dynamic Estimation

\begin{tabular}{lccc}
\hline VARIABLES & $(1)$ & $(2)$ & $(3)$ \\
\hline GCI (-1) & $0.4905 * * *$ & $0.4787 * * *$ & $0.5039 * * *$ \\
& $(5.7227)$ & $(5.3091)$ & $(5.8349)$ \\
Technology & $0.0630 * * *$ & $0.0687 * * *$ & $0.0608^{* *}$ \\
competitiveness (T) & $(2.6731)$ & $(2.9292)$ & $(2.5330)$ \\
Capacity & $0.0597 * * *$ & $0.0639 * * *$ & $0.0591 * * *$ \\
competitiveness (C) & $(3.4310)$ & $(3.5893)$ & $(3.4271)$ \\
Price & -0.0251 & -0.0576 & -0.0153 \\
competitiveness (P) & $(-0.1736)$ & $(-0.3959)$ & $(-0.1053)$ \\
\hline High-tech variable & & & \\
\hline High-tech trade & $0.1057 * * *$ & & \\
(TT) & $(2.6412)$ & & \\
High-tech exports & & $0.0692^{*}$ & \\
(XT) & & $(1.8978)$ & \\
High-tech imports & & & $0.1034 * * *$ \\
(MT) & & & $(2.7511)$ \\
Observations & 167 & 167 & 167 \\
Number of code & 19 & 19 & 19 \\
\hline z-statistics in parentheses & & \\
$* * *$ p $<0.01, * *$ p $<0.05, * p<0.1$ & & \\
& & & \\
\hline
\end{tabular}

\section{CONCLUSION}

The high-tech trade is expanding following the period of the Industrial Revolution. The expansion of hightech trade is highly associated with rapid technological changes. Theories predict that technology and innovation will enhance national competitiveness. However, the competitiveness level of high-tech exporters remains low. This paper aims to examine the impact of high-tech trade, exports and imports, on national competitiveness. Using a panel data set of 20 high-tech exporters throughout the period 2007-2016, this study found evidence of the positive relationship between high-tech trade and national competitiveness. Both high-tech exports and imports positively contribute to a higher level of national competitiveness. This paper also documents that price competitiveness is trivial as compared to other aspects of competitiveness.

The findings of this paper have some policy and economic implications. Engaging in high-tech trade has the potential to enhance national competitiveness. In other words, high-tech trade enhances the ability of a nation to achieve higher productivity, prosperity, and economic well-being. As such, countries should give more emphasis on the development of the high-tech industry. The exports of high-tech must be accompanied by an increase in technological capability to realise an increase in national competitiveness. Furthermore, policy to facilitate knowledge transfer through imported high-tech products should be strengthened. Besides, it 
is worth noting that price competitiveness is no longer significant to national competitiveness in the case of high-tech exporters. Instead of competing as a lowcost producer, countries should compete on innovation that could upgrade the national competitiveness level. This study involves a small sample size limiting the generalisation of the findings. Hence, future research should consider a larger number of observations for a more robust conclusion.

\section{REFERENCES}

Acharya, R. C., \& Keller, W. 2009. Technology transfer through imports. Canadian Journal of Economics/Revue Canadienne d'économique 42(4): 1411-1448.

Aiginger, K. 1998. A framework for evaluating the dynamic competitiveness of countries. Structural Change and Economic Dynamics 9(2): 159-188.

Aiginger, K. 2006. Competitiveness: from a dangerous obsession to a welfare creating ability with positive externalities. Journal of Industry, Competition and Trade 6(2): 161-177.

Arellano, M. and Bond, S. 1991. Some Tests of Specification for Panel Data: Monte Carlo Evidence and an Application to Employment Equations. The Review of Economic Studies 58(2): 277.

Artto, E. W. 1987. Relative total costs: an approach to competitiveness measurement of industries. Management International Review 27(2): 47-58.

Atkin, D., Khandelwal, A. K., \& Osman, A. 2017. Exporting and firm performance: Evidence from a randomised experiment. The Quarterly Journal of Economics 132(2): 551-615.

Baldwin, R., Gonzalez, A., Jackson, S., Murphy, K., Sally, R., \& Singh, V. H. 2015. The Case for Trade and Competitiveness. World Economic Forum.

Bao, Q., Sun, P., \& Su, L. 2012. Do High-technology Exports Cause More Technology Spillover in China?. China \& World Economy 20(2): 1-22.

Belitz, H., \& Mölders, F. 2016. International knowledge spillovers through high-tech imports and R\&D of foreign-owned firms. The Journal of International Trade \& Economic Development 25(4): 590-613.

Blundell, R., and Bond, S. 1998. Initial Conditions and Moment Restrictions in Dynamic Panel Data Models. Journal of Econometrics 87(1): 115-143.

Breene,K. 2016. What is 'networked readiness' and why does it matter?. https://www.weforum.org/agenda/2016/07/ what-is-networked-readiness-and- why- does-it- matter/ (accessed 26 November 2020).

Bruno, G.S.F. 2005a. Approximating the Bias of the LSDV Estimator for Dynamic Unbalanced Panel Data Models. Economics Letters 87(3): 361-366.

Bruno, G.S.F. 2005b. Estimation and Inference in Dynamic Unbalanced Panel-Data Models with a Small Number of Individuals. Stata Journal 5(4): 473-500.

Buckley, P. J., Pass, C. L., \& Prescott, K. 1988. Measures of international competitiveness: a critical survey. Journal of marketing management, 4(2): 175-200.

Bun, M. J., \& Kiviet, J. F. 2003. On the diminishing returns of higher-order terms in asymptotic expansions of bias. Economics Letters 79(2): 145-152.
Busse, M., \& Groizard, J. L. 2008. Technology trade in economic development. World Economy 31(4): 569-592.

Charrass, A. 2017. New Criticism on the Competitiveness Concept: A Critical Review of the Concept at the Macroeconomic Level. International Journal of Economics and Finance 9(1): 190-193.

Chen, W. C. 2013. The extensive and intensive margins of exports: The role of innovation. The World Economy 36(5): 607-635.

Coe, D. T., Helpman, E., \& Hoffmaister, A. W. 1997. Northsouth R \& D spillovers. The Economic Journal 107(440): 134-149.

Dayasindhu, N. 2002. Embeddedness, knowledge transfer, industry clusters and global competitiveness: a case study of the Indian software industry. Technovation 22(9): 551560.

Coe, D. T., Helpman, E., \& Hoffmaister, A. W. 1997. Northsouth R \& D spillovers. The Economic Journal 107(440): 134-149.

Delgado, M., Ketels, C., Porter, M. E., \& Stern, S. 2012. The determinants of national competitiveness. National Bureau of Economic Research Working Paper Series No. w18249.

Demir, O. 2018. Does High Tech Exports Really Matter for Economic Growth A Panel Approach for Upper MiddleIncome Economies. AJIT-e: Online Academic Journal of Information Technology 9(30): 43.

Ekananda, M., \& Parlinggoman, D. J. 2017. The role of hightech exports and of foreign direct investments (FDI) on economic growth. European Research Studies Journal 20(4A): 194-212

Fagerberg, J. 1988. International competitiveness. The Economic Journal 98(391): 355-374.

Fagerberg, J. 1996. Technology and competitiveness. Oxford Review of Economic Policy 12(3): 39-51.

Fagerberg, J., Srholec, M., \& Knell, M. 2007. The competitiveness of nations: Why some countries prosper while others fall behind. World Development 35(10): 1595-1620.

Falk, M. 2009. High-tech exports and economic growth in industrialised countries. Applied Economics Letters 16(10): 1025-1028.

Falvey, R., Foster, N., \& Greenaway, D. 2009. Trade, imitative ability and intellectual property rights. Review of World Economics 145(3): 373-404.

Gani, A. 2008. Technological achievement, high technology exports and growth. Journal of Comparative International Management 12(2): 31-47.

Ismail, N. W. 2013. Innovation and high-tech trade in Asian countries. Paper presented at International Conference on Recent Developments in Asian Trade Policy and Integration. 20-21 February, Kuala Lumpur Teaching Centre, the University of Nottingham Malaysia Campus.

Judson, R. A., \& Owen, A. L. 1999. Estimating dynamic panel data models: a guide for macroeconomists. Economics Letters 65(1): 9-15.

Kabaklarli, E., Duran, M. S., \& Üçler, Y. T. 2017. The Determinants of High-Technology Exports: A Panel Data Approach for Selected Oecd Countries. In DIEM: Dubrovnik International Economic Meeting 3(1): 888-900.

Kiviet, J.F. 1995. On Bias, Inconsistency, and Efficiency of Various Estimators in Dynamic Panel Data Models. Journal of Econometrics 68(1): 53-78. 
Krugman, P. 1994. Competitiveness: a dangerous obsession. Foreign Aff. 73: 28-44.

Levchenko, A. A. 2012. International trade and institutional change. The Journal of Law, Economics, \& Organization 29(5): 1145-1181.

Liu, X., \& Buck, T. 2007. Innovation performance and channels for international technology spillovers: Evidence from Chinese high-tech industries. Research Policy 36(3): 355-366

Mehrara, M., Seijani, S., \& Karsalari, A. R. 2017. Determinants of high-tech export in developing countries based on Bayesian model averaging.

Meschi, E., and M. Vivarelli. 2009. Trade and Income Inequality in Developing Countries. World Development 37(2): 287-302.

Muller, D., \& Wei, W. W. 1997. Iterative least squares estimation and identification of the transfer function model. Journal of Time Series Analysis 18(6):579-592.

Onsel, S., Ulengin, F., Ulusoy, G., Aktaş, E., Kabak, O., \& Topcu, Y. I. 2008. A new perspective on the competitiveness of nations. Socio-Economic Planning Sciences 42(4): 221-246.

Porter, M. E. 1990. The Competitive Advantage of Nations. Harvard Business Review 68(2): 73-93.

Romer, P. M. 1990. Endogenous technological change. Journal of Political Economy 98(5): S71-S102.

Sandu, S., \& Ciocanel, B. 2014. Impact of R\&D and Innovation on High-tech Export. Procedia Economics and Finance 15: 80-90.

Schwab, K. 2018. The global competitiveness report 2018. World Economic Forum.

Šegota, A., Tomljanović, M., \& Huđek, I. 2017. Contemporary approaches to measuring competitiveness-the case of EU member states. Journal of Economics and Business 35(1): 123-150

Seung-Ho,Yoo. 2008. High-technology exports and economic output: an empirical investigation. Applied Economics Letters 15(7): 523-525.

Siudek, T., \& Zawojska, A. 2014. Competitiveness in the economic concepts, theories and empirical research. Acta Scientiarum Polonorum. Oeconomia, 13(1): 91108.

Srholec, M. 2007. High-tech exports from developing countries: A symptom of technology spurts or statistical illusion?. Review of World Economics 143(2): 227-255.

Taner, B., Oncu, S., \& Civi, E. 2000. The relationship between international trade and national competitiveness. First International Joint Symposium on Business Administration Challenges for Business Administrators in the New Millennium: Selected Papers, 1-3 June, Gökçeada - Çanakkale, Turkey.
Tomáš, V. 2011. National competitiveness and expenditure on education, research and development. Journal of Competitiveness 2: 3-10.

Wabiga, P., \& Nakijoba, S. 2018. High Technology Exports, Gross Capital Formation and Economic Growth in Uganda: A Vector Auto Regressive Approach. International Journal of Business and Economics Research 7(6):191-202.

Wang, T. Y., Chien, S. C., \& Kao, C. 2007. The role of technology development in national competitivenessEvidence from Southeast Asian countries. Technological Forecasting and Social Change 74(8): 1357-1373.

World Bank. 2008. Global economic prospects 2008: Technology diffusion in the developing world. The World Bank.

Wu, J., Ma, Z., \& Zhuo, S. 2017. Enhancing national innovative capacity: The impact of high-tech international trade and inward foreign direct investment. International Business Review 26(3): 502-514.

Xing, Y. 2014. China's high-tech exports: The myth and reality. Asian Economic Papers 13(1): 109-123.

Zera Zuryana Idris*

Kulliyyah of Economics \& Management Sciences

International Islamic University Malaysia

P.O. Box 10, 50728 Kuala Lumpur

MALAYSIA

E-mail: zerazuryana@iium.edu.my

Normaz Wana Ismail

School of Business and Economics

Universiti Putra Malaysia

43400 UPM Serdang, Selangor

MALAYSIA

E-mail: nwi@upm.edu.my

Saifuzzaman Ibrahim

School of Business and Economics

Universiti Putra Malaysia

43400 UPM Serdang, Selangor

MALAYSIA

E-mail: saifuzzaman@upm.edu.my

Hanny Zurina Hamzah

School of Business and Economics

Universiti Putra Malaysia

43400 UPM Serdang, Selangor

MALAYSIA

E-mail: hannyzurina@upm.edu.my

*Corresponding author 
APPENDIX A. Definition of competitiveness

\begin{tabular}{|c|c|c|}
\hline Author (s) & Definition & Measurement \\
\hline Fagerberg (1988) & $\begin{array}{l}\text { Competitiveness is the development in the market share } \\
\text { contributed by the ability to compete in technology, the } \\
\text { ability to compete in capacity and the ability to compete } \\
\text { in price. }\end{array}$ & $\begin{array}{l}\text { Growth of market share of exports } \\
\text { and imports }\end{array}$ \\
\hline $\begin{array}{l}\text { Buckley, Pass and Prescott } \\
\text { (1988) }\end{array}$ & $\begin{array}{l}\text { Useful measures of competitiveness must specify the } \\
\text { level of analysis and include competitive performance, } \\
\text { competitive potential and competitive process. }\end{array}$ & $\begin{array}{l}\text { Market share of export; percentage } \\
\text { of manufacturing in total output; } \\
\text { Balance of trade; Export growth; } \\
\text { Profitability }\end{array}$ \\
\hline Porter (1990) & $\begin{array}{l}\text { Competitiveness is the ability of an economy to secure } \\
\text { high living standards and high employment rate. The } \\
\text { most meaningful concept of national competitiveness is } \\
\text { national productivity. }\end{array}$ & \\
\hline Krugman (1994) & $\begin{array}{l}\text { Competitiveness is a meaningless word when applied to } \\
\text { national economies }\end{array}$ & \\
\hline Aiginger (1998) & $\begin{array}{l}\text { Competitiveness is the ability of a nation to sell enough } \\
\text { products and services in the world in line with the } \\
\text { economic and policy goals of the country. }\end{array}$ & $\begin{array}{l}\text { External balance, factor incomes and } \\
\text { macroeconomics conditions }\end{array}$ \\
\hline Artto (1987) & $\begin{array}{l}\text { Competitiveness of a nation is the degree to which it can, } \\
\text { under free and fair market conditions, produce goods and } \\
\text { services that meet the standards of international markets } \\
\text { while simultaneously expanding the real income of its } \\
\text { citizens, thus improving their quality of life. }\end{array}$ & \\
\hline Onsel et.al (2008) & $\begin{array}{l}\text { A nation's competitiveness can be viewed as its position } \\
\text { in the international marketplace compared to other } \\
\text { nations of similar economic development. }\end{array}$ & \\
\hline Tomas (2011) & $\begin{array}{l}\text { Viewed national competitiveness as macroeconomic } \\
\text { competitiveness and the definition includes the standard } \\
\text { of living and human well-being }\end{array}$ & Human Development Index (HDI) \\
\hline $\begin{array}{l}\text { Segota, Tomljanovik \& } \\
\text { Hudjek (2017) }\end{array}$ & $\begin{array}{l}\text { Competitiveness at the macro level is a wider term that } \\
\text { includes growth, quality of life, and productivity. }\end{array}$ & \\
\hline Schwab (2017) & $\begin{array}{l}\text { National competitiveness is the set of institutions, } \\
\text { policies, and factors that determine the level of } \\
\text { productivity of a country. }\end{array}$ & Global Competitiveness Index (GCI) \\
\hline
\end{tabular}

Source: Author's compilation based on existing literature 